\title{
Incidence of ulcerative colitis in Cardiff over 20 years: $1968-87$
}

E D Srivastava, J F Mayberry, T J Morris, P M Smith, G T Williams, G M Roberts, R G Newcombe, J Rhodes

\begin{abstract}
The annual incidence of ulcerative colitis in the city of Cardiff was examined over a 20 year period. In the decade $1968-77$, the mean annual incidence was 6.4 per $10^{5}$ of the population compared with $6 \cdot 3$ for the period $1978-87$. There was no difference in the distribution or extent of the disease between decades or between sexes. This contrasts with the increased incidence of Crohn's disease during the same period. The study included a survey of family practitioners which identified a further 19 patients (11\% of the total).
\end{abstract}

The incidences of both ulcerative colitis and Crohn's disease are now similar in most western countries. ${ }^{1}$ We have examined the incidence of ulcerative colitis in the city of Cardiff between 1968 and 1987 and made comparisons with Crohn's disease over the same period.

\section{Methods}

PATIENTS

The incidence of ulcerative colitis between 1968 and 1977 in the Cardiff region has previously been reported. ${ }^{2}$ These data were re-examined for those patients who were resident within the city limits using criteria defined at a workshop sponsored by the European Commission on the Epidemiology and Pathogenesis of Inflammatory Bowel Disease. ${ }^{3}$ In addition, more recent figures for the subsequent decade $1978-87$ were also determined.

The date at which the diagnosis of ulcerative colitis was first made was used to identify patients for the study and the interval from the onset of symptoms to diagnosis was noted. The extent of disease was determined by double contrast barium enema or colonoscopy, or both, and was defined as distal (confined to the rectum and sigmoid), left sided (with involvement

TABLE I Cases of ulcerative colitis (UC) identified from each source between 1978 and 1987

\begin{tabular}{|c|c|c|c|c|c|c|c|}
\hline Source of data & $H A A$ & Histology & Radiology & $\begin{array}{l}\text { GI letter } \\
\text { index }\end{array}$ & $\begin{array}{l}\text { Paediatric } \\
\text { letter index }\end{array}$ & GPs & $\begin{array}{l}\text { Total no of } \\
\text { case notes } \\
\text { reviewed }\end{array}$ \\
\hline $\begin{array}{l}\text { UC diagnosed in Cardiff residents } 1978-87 \\
\text { UC diagnosed before } 1978 \text { or after } 1987 \\
\text { UC non-resident in Cardiff city } \\
\text { UC diagnosed outside Cardiff }{ }^{\star} \\
\text { Crohn's disease } \\
\text { Irritable bowel } \\
\text { Other diagnoses }\end{array}$ & $\begin{array}{r}77 \\
65 \\
72 \\
9 \\
8 \\
8 \\
10\end{array}$ & $\begin{array}{r}35 \\
18 \\
51 \\
3 \\
5 \\
0 \\
0\end{array}$ & $\begin{array}{r}9 \\
9 \\
24 \\
0 \\
2 \\
0 \\
3\end{array}$ & $\begin{array}{r}36 \\
88 \\
0 \\
4 \\
3 \\
0 \\
0\end{array}$ & $\begin{array}{r}0 \\
3 \\
0 \\
0 \\
17 \\
0 \\
0\end{array}$ & $\begin{array}{r}19 \\
56 \\
0 \\
88 \\
37 \\
5 \\
15\end{array}$ & $\begin{array}{r}176 \\
239 \\
147 \\
24 \\
72 \\
13 \\
28\end{array}$ \\
\hline Total no of cases reviewed from each source & 249 & 180 & 47 & 200 & 20 & 214 & 699 \\
\hline
\end{tabular}

$\mathrm{HAA}=$ hospital activity analysis.

«Ulcerative colitis diagnosed outside Cardiff but patient moved to Cardiff after the diagnosis was made.

Prince Charles Hospital, Merthyr Tydfil, Glamorgan J T Morris

Correspondence to: Professor John Rhodes, Department of Gastroenterology, University Hospital of Wales, Heath Accepted for publication 7 May 1991

Departments of
Gastroenterology,
Pathology, Radiology,
and Medical Statistics,
University Hospital of
Wales, Cardiff
E D Srivastava
G T Williams
G M Roberts
R G Newcombe
J Rhodes
Department of
Gastroenterology,
Llandough Hospital,
Penarth, South
Glamorgan
P M Smith
Department of
Gastroenterology,
Leicester General
Hospital, Leicester
J F Mayberry
Prince Charles Hospital,
Merthyr Tydfil,
Glamorgan
J T Morris
Correspondence to:
Professor John Rhodes,
Department of
Gastroenterology, University
Hospital of Wales, Heath
Park, Cardiff CF4 4XW.
Accepted for publication
7 May 1991

proximal to the sigmoid), and total (extending proximally to the mid-transverse colon).

Cases were identified by first checking the hospital activity analysis of inpatients, then diagnostic indices from the departments of pathology and radiology, and finally letter indices of two gastroenterologists in Cardiff. In addition, a questionnaire was sent to all 227 general practitioners in South Glamorgan asking them to identify patients with ulcerative colitis in their practice. Altogether $80 \%$ of practitioners replied to the questionnaire, and the remaining $20 \%$, who were subsequently contacted by telephone, were unable to identify patients from their register. During this search the case notes from 699 patients were reviewed and 176 with ulcerative colitis were identified who fulfilled the accepted criteria (Table I).

The Registrar General's mid-year estimates for the population of Cardiff with its age and sex structure were used to calculate incidence and age specific incidence. Age standardisation of the difference between the two decades was effected by Cochran's method. ${ }^{+}$Statistical analysis was performed by $\chi^{2}$ test, using Yates's correction.

\section{Results}

We identified 357 residents of the City of Cardiff whom the diagnosis of ulcerative colitis was first made between 1 January 1968 and 31 December 1987. There were 180 men and 177 women. The median age at diagnosis in men was 33 years (range 12-78 years) and in women 36 years (range 12-87 years). The numbers identified from different sources together with the percentage they constituted of the total are shown in Table I. Seventy seven (44\%) were identified from the hospital activity analysis of inpatients (which involved a review of 249 case notes), a further $35(20 \%)$ patients from pathology records, nine $(5 \%)$ from the radiology index, $36(20 \%)$ from the gastroenterology letter indices, and finally 19 additional patients $(11 \%)$ 


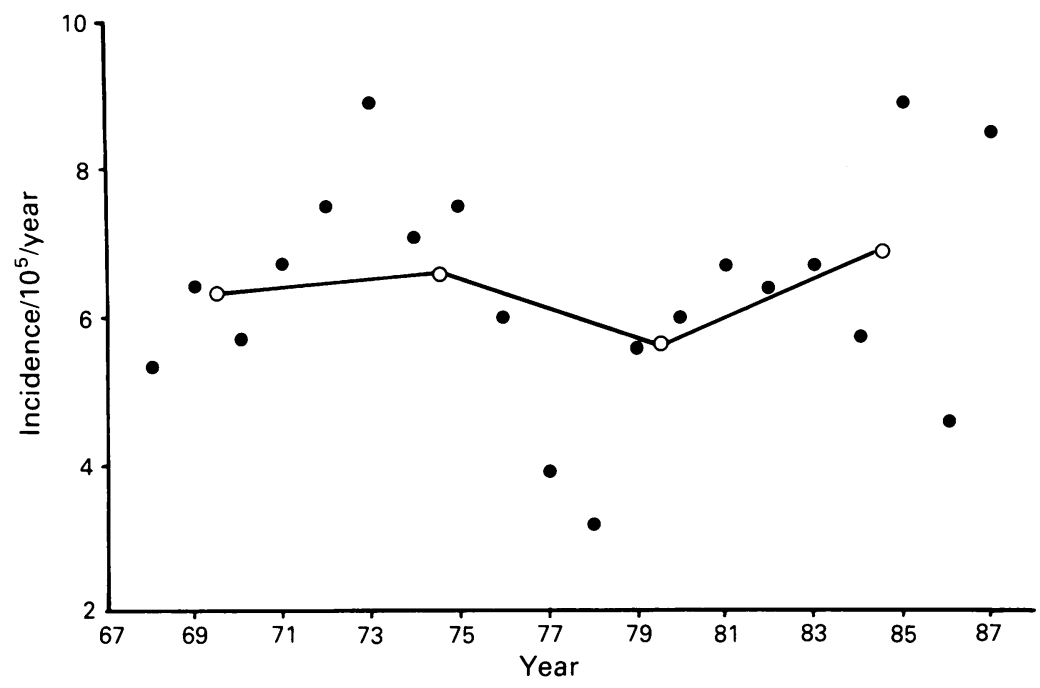

Figure 1: Annual incidence of ulcerative colitis between 1968 and 1987, with mean five year aggregates. from 8.9 months (range 0 to 19 years) during the period $1968-77$ to $5 \cdot 1$ months (range $0-3$ years) in the second decade 1978-87. At the time of diagnosis 194 patients had distal disease only $(54 \cdot 4 \%), 80$ had left sided disease $(22 \cdot 4 \%)$, and 83 total colitis $(23 \cdot 2 \%)$ (Fig 3 ). The extent of disease showed a similar distribution in all age groups. There was no significant difference in the distribution of the extent of disease between the two decades $\left(\chi^{2}=1 \cdot 57, \mathrm{NS}\right)$ or between the sexes $\left(\chi^{2}=3.95, \mathrm{NS}\right)$. Incident cases were predominantly female in the first decade $(99 / 181$; $55 \%)$ and male in the second $(98 / 176 ; 56 \%)$. The difference in sex distribution between the decades was of borderline significance $\left(\chi^{2}=3 \cdot 84\right.$, $\mathrm{p}<0.05$ ).

\section{Discussion}

The incidence of colitis in Cardiff city between 1968 and 1987 remained steady at about 6.3 per $10^{5}$. Figures from the second decade 1978-87 were traced by the family practitioner questionnaire.

The mean annual incidence for the whole period was 6.3 per $10^{5}$ inhabitants, and the figures for men and women were $6 \cdot 1$ and 6.6 respectively. The annual incidence over the 20 years, together with five year aggregates, are given in Figure 1. Despite considerable variation between annual values, the overall incidence for five year periods showed little change. Standardised for age, the incidence during the two decades $1968-77$ and 1978-87 gave marginally lower values in the second decade $\left(0.37\right.$ per $10^{5}$ per year lower, $95 \%$ confidence interval $-1 \cdot 69$, +0.95 ), a non-significant reduction. Figures for the first decade are lower than reported by us previously, ${ }^{2}$ because the survey was limited to the city and diagnostic criteria were changed slightly. ${ }^{3}$

The incidence of colitis in different age groups was expressed as the age specific incidence (Figure 2). Colitis continues to be rare in childhood, although the incidence increased throughout the second and third decades of life and remained high thereafter with some suggestion of a bimodal age distribution during the period 1978-87. The mean interval from onset of symptoms to diagnosis was 7 months; this was reduced

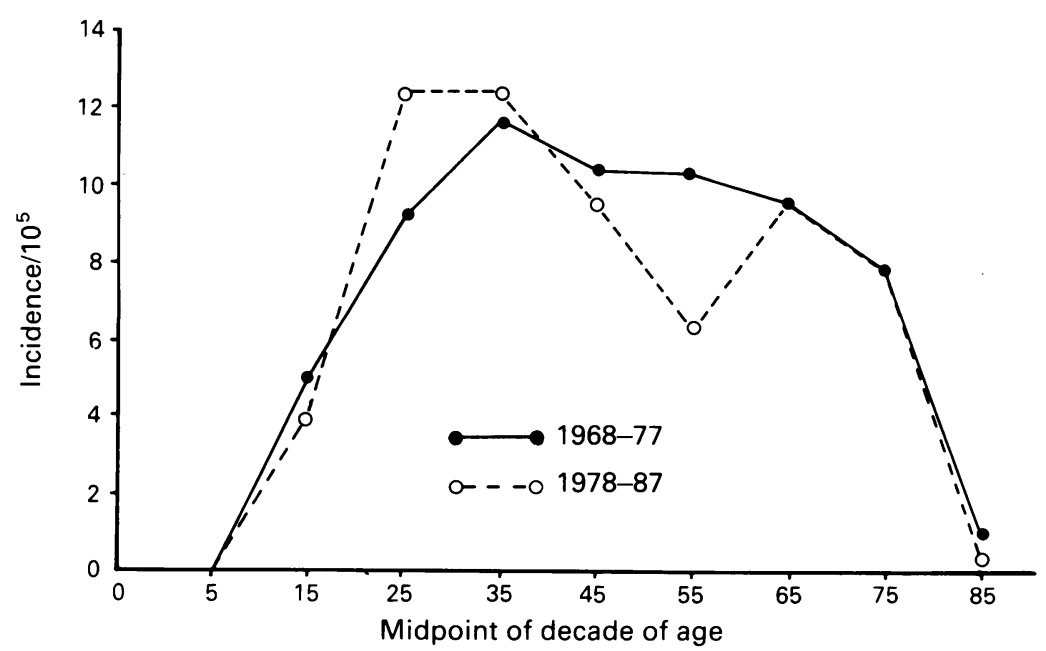

Figure 2: Age specific incidence of ulcerative colitis during the decades 1968-77 and 1978-87. show that the disease continues to be rare in childhood but remains uniformly high throughout most of adult life. Data for both decades were collected in a similar manner. The Cardiff hospitals have an excellent diagnostic index of inpatients, which has been computerised since 1968. A clinic for inflammatory bowel disease was estabished in 1965, initially at the Cardiff Royal Infirmary and more recently at the University Hospital of Wales. Patients are referred to this clinic both by family practitioners and hospital consultants. Since the diagnostic indices from both the radiology and pathology departments were not computerised, all the family practitioners in South Glamorgan were also contacted to identify additional patients; this last procedure was not undertaken during the initial study of 1968-77. ${ }^{2}$ A further 19 cases were identified as a consequence of this additional measure. If this were extrapolated to the first decade and a similar number of additional patients had been identified, the incidence would have been $7 \cdot 1$ per $10^{5}$. The implication, if this were the case, would be a fall in the true incidence of colitis in the city over the 20 years from $7 \cdot 1$ to $6 \cdot 3$ per $10^{5}$. These figures contrast sharply with comparable data for Crohn's disease in Cardiff, which show a rise in incidence, ${ }^{5}$ but the difference cannot simply be explained on the basis of greater accuracy in diagnosis.

Results from comparable studies on changes in the incidence of ulcerative colitis show variable results. In some, the incidence seems relatively stable (between 4 and 9 per $10^{5}$ in Sweden, ${ }^{6}$ USA, ${ }^{7}$ England, ${ }^{8}$ and Wales ${ }^{2}$ ), while other studies show an increase (Iceland, Scotland, ${ }^{10}$ Faroe Islands, ${ }^{11}$ and Norway $\left.{ }^{12}\right)$. It is difficult to be sure whether those studies which show a rise in incidence reflect the true situation or a change in case ascertainment. We would place more confidence on quinquennial rather than annual figures because the latter are subject to considerable variation. In Japan, colitis is at least 10 times less common than in western Europe..$^{1314}$ The incidence values from various countries are given in Table II.

The incidence of colitis in Cardiff has shown little change over the 20 year period compared 


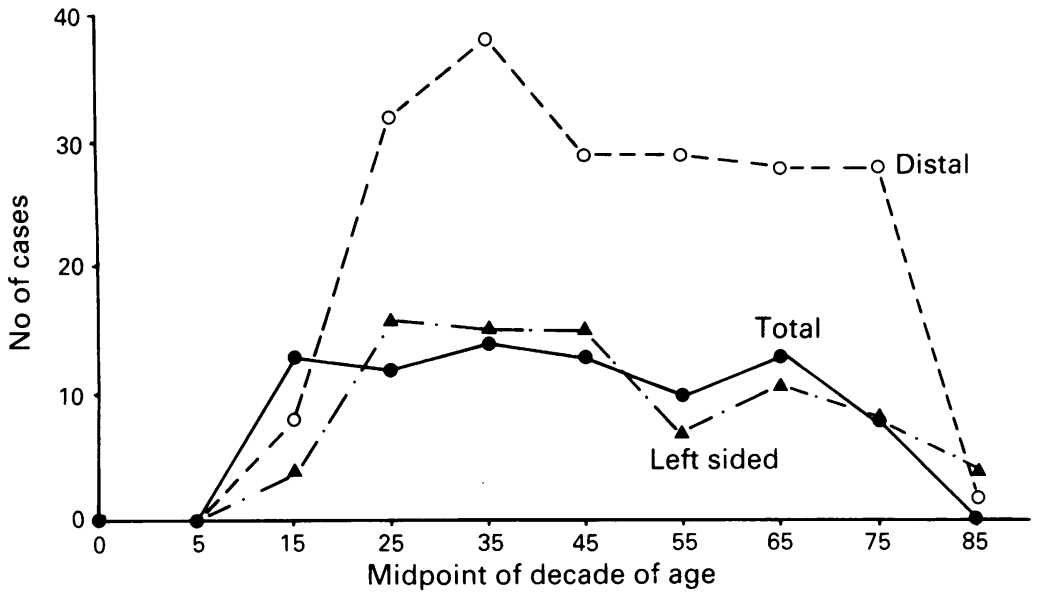

Figure 3: Extent of ulcerative colitis, defined as distal, left sided, and total, at the time of diagnosis in 10 year age bands for 1968-87.

TABLE II Studies from different centres showing the incidence of ulcerative colitis

\begin{tabular}{|c|c|c|}
\hline Centre & Date & $\begin{array}{l}\text { Incidence } \\
\text { (cases } / 10^{\prime} / y r\end{array}$ \\
\hline \multicolumn{3}{|l|}{ Great Britain: } \\
\hline Cardiff (present study) & $1968-87$ & $6 \cdot 3$ \\
\hline Oxford ${ }^{x}$ & $1951-60$ & $6 \cdot 5$ \\
\hline North Tees ${ }^{15}$ & $1971-77$ & $15 \cdot 1$ \\
\hline Grampian region" & $1967-76$ & $11 \cdot 3$ \\
\hline \multirow{2}{*}{ Lothian region ${ }^{16}$} & $1968-71$ & $2 \cdot 6$ \\
\hline & 1976-79 & $4 \cdot 0$ \\
\hline High Wycombe & $1976-84$ & $6 \cdot 7$ \\
\hline \multicolumn{3}{|l|}{ Scandinavia: } \\
\hline Faroe Islands" & $1964-83$ & $7 \cdot 5$ \\
\hline \multirow[t]{3}{*}{ Iceland ${ }^{4}$} & $1950-59$ & $2 \cdot 8$ \\
\hline & $1960-69$ & $4 \cdot 7$ \\
\hline & $1970-79$ & $7 \cdot 4$ \\
\hline \multirow[t]{2}{*}{ Sweden - Stockholm County ${ }^{6}$} & $1955-59$ & $1 \cdot 7$ \\
\hline & $1975-79$ & $4 \cdot 3$ \\
\hline Norway $^{18}$ & $1983-86$ & $12 \cdot 8$ \\
\hline \multicolumn{3}{|l|}{ Europe: } \\
\hline Netherlands - Zuid ${ }^{14}$ & $1979-83$ & $6 \cdot 8$ \\
\hline Germany - Ruhrgebeit ${ }^{20}$ & $1980-84$ & $2 \cdot 9^{\star}$ \\
\hline \multirow{2}{*}{ Hungary - County Borsod"1 } & $1963-72$ & $3 \cdot 1$ \\
\hline & $1972-83$ & $3 \cdot 1$ \\
\hline \multirow{7}{*}{$\begin{array}{l}\text { Israel: } \\
\text { Tel-Aviv-Jaffo:" } \\
\text { Beer Sheeva }{ }^{33}\end{array}$} & & \\
\hline & $1961-70$ & $3 \cdot 7$ \\
\hline & $1980-84$ & \\
\hline & All & $5 \cdot 8$ \\
\hline & Israeli born & $4 \cdot 4$ \\
\hline & Afro-Asian born & $5 \cdot 6$ \\
\hline & European-American born & $10 \cdot 8$ \\
\hline \multirow[t]{3}{*}{ New Zealand ${ }^{4}$} & $1969-78$ & \\
\hline & Whites & $5 \cdot 4$ \\
\hline & Polynesians & $0 \cdot 4$ \\
\hline \multirow{6}{*}{$\begin{array}{l}\text { USA - Rochester, Minnesota } \\
\text { Japan } \\
\text { South Africa - Capetown }{ }^{2 \varsigma}\end{array}$} & $1960-79$ & $15 \cdot 0$ \\
\hline & 1980 & $0 \cdot 4$ \\
\hline & $1980-84$ & \\
\hline & Whites & $5 \cdot 0$ \\
\hline & Coloureds & 1.9 \\
\hline & Jews & $17 \cdot 0$ \\
\hline Czechoslovakia - North Bohemia & 1978 & $1 \cdot 3$ \\
\hline
\end{tabular}

${ }^{\star}$ Excluding proctitis. because the intensity with which patients are sought must inevitably affect the ultimate total; this phenomenon may well be a more general one in relation to other chronic disease states.

1 Mayberry JF. Recent epidemiology of ulcerative colitis and Crohn's disease. Int f Colorectal Dis 1989; 4: 59-66.

2 Morris T, Rhodes J. Incidence of ulcerative colitis in the Cardiff region, 1968-1977. Gut 1984; 25: 846-8.

3 Lennard-Jones JE. Classification of inflammatory bowel disease. Scand F Gastroenterol 1989; 24 (suppl 1): 2-6.

Armitage P, Berry G. Statistical methods in medical research. 2nd Ed. Oxford: Blackwell, 1987: 382.

5 Rose JDR, Roberts GM, Williams G, Mayberry JF, Rhodes J. Cardiff Crohn's disease jubilee: the incidence over 50 years. Gut 1988; 29: 346-51.

6 Nordenwall B, Brostrom O, Berglund M, Monsén U, Nordenstrom J, Sorstad J, et al. Incidence of ulcerative colitis in Stockholm County 1955-79. Scand f Gastroenterol colitis in Stockho

7 Stonnington CM, Phillips SF, Melton LJ, Zinsmeister AR. Chronic ulcerative colitis: incidence and prevalence in a community. Gut 1987; 28: 402-9.

8 Evans JG, Achieson ED. An epidemiological study of ulcerative colitis and regional enteritis in the Oxford area. Gut 1965; 6: 311-24.

9 Björnsson S, Thorgeirsson R. Colitis ulceros i Island. Epidemiologisk unders okning 1950-1979. Nor Med 1983; 98: 298-301.

10 Sinclair TS, Brunt PW, Ashley N, Morwat G. Non-specific proctocolitis in North eastern Scotland: a community study. Gastroenterology 1983; 85: 1-11.

11 Berner J, Kiaer T. Ulcerative colitis and Crohn's disease on the Faroe Islands 1964-1983. Scand $\mathcal{F}$ Gastroenterol 1986; 21: 188-92.

2 Haug K, Schrumpf E, Barstad S, Fluge G, Halvorsen JF, and the study group of inflammatory bowel disease in Western Norway. Epidemiology of ulcerative colitis in western Norway. Scand F Gastroenterol 1988; 23: 517-22.

3 Utsunomiya T, Shinohara Y, Kitahara T, Suzuki K, Yokota A. Epidemiological study on the incidence of idiopathic proctocolitis in Japan - an Enquete study. In: Shiration T, Nakano H, eds. Japan Medical Research Foundation Publication 22. Inflammatory bowel disease. Tokyo: University of Tokyo, 1984: 185-9.

14 Utsunomiya T, Yoshida T, Takanami I, Bessho T, Sinohara $\mathrm{H}$, Suzuki K, et al. Incidence and prevalence of idiopathic proctocolitis in Japan. Dig Dis Sci 1986; 31 (suppl): 221.

15 Devlin HB, Datta D, Dellipiani AW. The incidence and prevalence of inflammatory bowel disease in North Tees Health District. World F Surg 1980; 4: 183-93.

16 Entrican JH, Sircus W. Changes in the epidemiology, clinical presentation and behaviour of inflammatory bowel disease occurring in South-East Scotland. In: McConnell R, Rozen $\mathrm{P}$, Langman $M$, Gilat $T$, eds. The genetics and epidemiology of inflammatory bowel disease. Basel: Karger, 1986.

17 Jones HW, Grogons J, Hoare AM. An audit of ulcerative colitis in a district general hospital. Gut 1985; 26: Al123.

18 Kildebo S, Nordgaard K, Aronsen O, Breckan R, Burhol PG. Jorde R. The incidence of ulcerative colitis in Northern Norway from 1983 to 1986. Scand F Gastroenterol 1990; 25: $890-6$.

19 Shivananda S, Pẽna AS, Mayberry JF, Ruitenberg EJ, Hoedemaeker PHJ. Epidemiology of proctocolitis in the region of Leiden, The Netherlands. A population study from 1979 to 1983. Scand $\mathcal{F}$ Gastroenterol 1987; 22: 9931002.

20 Dirks E, Forster S, Goebell H. Incidence and prevalence of chronic inflammatory bowel disease in a prospective study from an industrial area in West Germany. Dig Dis Sci 1986; 31 (suppl): 83.

21 Pronay GG, Nagy G, Ujszasky L, Minik K. Inflammatory bowel disease in County Borsod, Hungary: a 20 year survey. In: de Dombal FT, Myren J, Bouchier IAD, Watkinson G, In: de Dombal FT, Myren J, Bouchier IAD, Watkinson G, eds. Inflammatory bowel disease. Some international data and

with the rise in Crohn's disease. The ratio of incidence for ulcerative colitis to Crohn's disease was $1: 0.5$ in 1968 and $1: 1.3$ in 1985 . The true prevalence of colitis may be considerably higher than the values we have recorded in view of a recent exercise in Nottingham which identified additional asymptomatic patients with colitis as an incidental finding while screening middle aged subjects for colonic cancer. The additional patients identified in this study suggest that current figures on prevalence may be increased by as much as $30 \%{ }^{27}$ Some care should be taken when comparing figures from different series

Gilat T, Ribak J, Benoroya Y, Zemishlany Z, Weissman I Ulcerative colitis in the Jewish population of Tel-Aviv-Jaffo. 1: Epidemiology. Gastroenterologv 1974; 66: 335-42.

23 Odes HS, Fraser D, Krawiec J. Ulcerative colitis in the Jewish population in Southern Israel 1961-1985: epidemiological and clinical study. Gut 1987; 28: 1630-6.

24 Easmon RJ, Lee SP, Tasman-Jones C. Inflammatory bowel disease in Auckland, New Zealand. Aust NZ F Med 1982; 12 125-31.

25 Wright JP, Froggatt J, O'Keefe EA, Ackerman S, Watermever $\mathrm{S}$, Louw J, et al. The epidemiology of inflammatory bowel disease in Cape Town 1980-1984. S Afr Med F 1986; 70: disease

26 Bitter J, Hulec J. Ulcerozni kolitida v severoceskem Kraji. Cesk Gastroenterol 1980; 34: 137-4t.

27 Ballantyne KC, Mayberry JF, Pye G, Mangham C, Hardcastle JD. Detection of asymptomatic inflammatory bowel disease while screening for colorectal cancer. Gut 1989; 30: 481-3. 